\title{
Preparation of Metal-Incorporated SAPO-34 catalysts and their Catalytic Performance in Selective Catalytic Reduction of Nitric Oxide
}

\author{
Dapeng Wang ${ }^{a}$, Yi Yang ${ }^{b}$, Chengwen Song * (D) \\ ${ }^{a}$ Dalian Maritime University, Navigation College, 1 Linghai Road, Dalian 116026, China \\ ${ }^{b}$ Dalian Maritime University, College of Environmental Science and Engineering, 1 Linghai Road, \\ Dalian 116026, China
}

Received: August 03, 2020; Revised: November 06, 2020; Accepted: November 11, 2020

\begin{abstract}
Metal-incorporated SAPO-34 catalysts were prepared by one-step hydrothermal method. Effects of various parameters including the types of metal ions, $\mathrm{Cu}^{2+}$ sources, structure directing agents (SDAs), hydrothermal temperature and time on catalyst activity of the metal-incorporated SAPO-34 catalysts were investigated. Three types of metal-incorporated SAPO-34 catalysts (Cu/SAPO-34, Fe/SAPO-34 and $\mathrm{Mn} / \mathrm{SAPO}-34$ ) were successfully obtained. Compared with Fe/SAPO-34 and Mn/SAPO-34 catalysts, $\mathrm{Cu} / \mathrm{SAPO}-34$ catalyst revealed complete cubic-like microstructure, wide active temperature window and high conversion rate in selective catalytic reduction (SCR) of nitric oxide. After defined $\mathrm{Cu}^{2+}$ was the favorable active site of SAPO-34 catalyst, the effects of four $\mathrm{Cu}^{2+}$ sources on SCR performance were further investigated, and found $\mathrm{Cu}^{2+}$ sources did not produce significant influence on nitric oxide conversion rates. SDAs determined the formation of $\mathrm{Cu} / \mathrm{SAPO}-34$ catalyst, and the $\mathrm{Cu} / \mathrm{SAPO}-34$ catalyst adopting tetraethylenepentamine (TEPA) as SDA could maintain higher crystal integrity and active sites, which were in favor of the SCR reaction. Moreover, hydrothermal temperature and time had great influences on the formation of $\mathrm{Cu} / \mathrm{SAPO}-34$ catalyst. When the hydrothermal temperature was higher than $150^{\circ} \mathrm{C}$ and the hydrothermal time was longer than 3 days, the $\mathrm{Cu} / \mathrm{SAPO}-34$ catalyst with a cubic-like structure and high catalyst activity could be obtained.
\end{abstract}

Keywords: Selective catalytic reduction, $\mathrm{Cu} / \mathrm{SAPO}-34$, catalyst activity, nitric oxide.

\section{Introduction}

Nitrogen oxides $\left(\mathrm{NO}_{\mathrm{x}}\right)$, as one of the major atmospheric pollutants, are mainly generated in the combustion of fossil fuels and biofuels, which have given rise to serious environmental problems including greenhouse effect, ozone depletion, acid rain ${ }^{1-5}$. At present, selective catalytic reduction (SCR) has been applied as one of the most effective methods on $\mathrm{NO}_{\mathrm{x}}$ removal in flue gas ${ }^{6-8}$. Compared with noble metal or oxides catalysts, SAPO-34 catalysts demonstrate high $\mathrm{NO}_{x}$ conversion efficient and arise widespread concern. However, SAPO-34 catalysts are extremely sensitive to humid environment, which easily causes serious structure deterioration because of the irreversible hydrolysis of bridge hydroxyl group ${ }^{9-11}$.

Recently, great efforts have been carried out to improve the SCR activity by doping transition metals into SAPO-34 catalysts. According to previous reports, Fe-incorporated catalyst exhibited enhanced $\mathrm{NO}_{\mathrm{x}}$ conversion at high temperature ${ }^{12-15}$. Mn-incorporated catalyst was also developed to improve low-temperature SCR activity ${ }^{16-18}$. Besides, introducting $\mathrm{Cu}^{2+}$ into SAPO-34 catalysts could increase theirs low-temperature hydrothermal stability owing to the enhanced stabilization of negative Si-O-Al connections ${ }^{19}$. Among the metal-incorporated catalysts, $\mathrm{Cu}$-incorporated catalysts demonstrated excellent potential owing to their low price, high catalytic activity, wide temperature range $\mathrm{e}^{20,21}$.

*e-mail: chengwensong@dlmu.edu.cn
Currently, Cu/SAPO-34 catalysts could be fabricated by three methods: impregnation, ion-exchange, and one-pot methods. Generally, the distribution of copper species is closely related to the synthesis method $^{22,23}$. Specially, ionexchange and one-pot methods were more favorable due to more active sites generation and less structure damages ${ }^{13,24,25}$. Wang et al. ${ }^{26}$ adopted ion-exchange method to fabricate $\mathrm{Cu} /$ SAPO-34 catalysts, which demonstrated $\mathrm{Cu}$ species existing as isolated ions were active sites for the SCR reaction. Fickel et al. ${ }^{20}$ also utilized ion-exchange method to fabricate $\mathrm{Cu} / \mathrm{SAPO}-34$ catalysts. Their work demonstrated $\mathrm{Cu} / \mathrm{SAPO}-34$ catalysts with high SCR activity could be achieved even after steaming. Meanwhile, Liu et al. ${ }^{27}$ reported their work on $\mathrm{Cu} /$ SAPO-34 catalysts obtained by ion-exchange method. They believed that the migration of surface $\mathrm{CuO}$ clusters into the ion-exchanged sites as isolated $\mathrm{Cu}^{2+}$ improved the activity at high temperatures, which suppressed the competitive oxidation of $\mathrm{NH}_{3}$. Cortés-Reyes et al. ${ }^{28}$ synthesized $\mathrm{Cu} / \mathrm{SAPO}-$ 34 catalysts in a one-pot process, and found $\mathrm{Cu}^{2+}$ existed in the interior of the cavities. Martínez-Franco et al. ${ }^{29}$ obtained $\mathrm{Cu} / \mathrm{SAPO}-34$ catalysts by adopting the co-directing SDA, and concluded that it was easy to control the $\mathrm{Cu}^{2+}$ loading in the $\mathrm{Cu} / \mathrm{SAPO}-34$ catalysts. Tang et al. ${ }^{30}$ investigated the effect of $\mathrm{Cu}^{2+}$ loading on the SCR activity of $\mathrm{Cu} / \mathrm{SAPO}-34$ synthesized by one-pot method.

Generally, ion-exchange method contains several complex steps, which needs long production period and 
produces a large amount of wastewater. In contrast, the one-pot method requires a simple hydrothermal synthesis, which is more economical and efficient preparation technology for $\mathrm{Cu} / \mathrm{SAPO}-34$. Inspired from previous researches, here, we fabricated metal-incorporated SAPO-34 catalysts by one-step hydrothermal synthesis, investigated the effects of various parameters including the types of metal ions, copper ion sources, SDAs, hydrothermal temperature and time on catalyst activity of metal-incorporated SAPO-34 catalysts, characterized the morphology, structure, and chemical composition of metal-incorporated SAPO-34 catalysts by SEM, XRD, XPS and $\mathrm{N}_{2}$ adsorption techniques.

\section{Experimental}

\subsection{Fabrication of catalysts}

Metal-incorporated SAPO-34 catalysts (Cu/SAPO-34, Fe/SAPO-34 and Mn/SAPO-34) were prepared by a onepot synthesis method. Figure 1 showed the schematic diagram for the preparation of metal-incorporated SAPO-34 catalysts. In the synthesis procedure, phosphoric acid was firstly dissolved in deionized water, and then silica source (fumed silica) and alumina source (pseudoboehmite) were added into the solution and stirred for $1 \mathrm{~h}$. Subsequently, metals ion sources $\left(\mathrm{Fe}\left(\mathrm{NO}_{3}\right) \cdot 9 \mathrm{H}_{2} \mathrm{O}, \mathrm{Mn}\left(\mathrm{CH}_{3} \mathrm{COO}\right)_{2} \cdot 4 \mathrm{H}_{2} \mathrm{O}\right.$ or $\mathrm{Cu}\left(\mathrm{CH}_{3} \mathrm{COO}\right)_{2} \cdot \mathrm{H}_{2} \mathrm{O}$ ) and SDAs (tetraethylenepentamine (TEPA)) were introduced to the above gel under continuous stirring for $3 \mathrm{~h}$. The molar composition of the synthesized gel was: 1Al:0.8P:0.18Si:0.58Metal (Fe, $\mathrm{Mn}$ or $\mathrm{Cu}): 0.4 \mathrm{SDA}$ (TEPA, TETA or DETA): $18 \mathrm{H}_{2} \mathrm{O}$. The resultant gel was sealed in a $100-\mathrm{ml}$ Teflon-lined autoclave, and crystallized in drying oven for 7 days at $150{ }^{\circ} \mathrm{C}$. The obtained products were centrifuged and washed with distilled water, then dried at $100{ }^{\circ} \mathrm{C}$ overnight, followed by calcination at $550{ }^{\circ} \mathrm{C}$ for $5 \mathrm{~h}$. In order to further optimize the preparation parameters of $\mathrm{Cu} / \mathrm{SAPO}$ 34 catalysts, various $\mathrm{Cu}^{2+}$ sources $\left(\mathrm{Cu}\left(\mathrm{CH}_{3} \mathrm{COO}\right)_{2} \cdot \mathrm{H}_{2} \mathrm{O}\right.$, $\mathrm{Cu}\left(\mathrm{NO}_{3}\right) \cdot 3 \mathrm{H}_{2} \mathrm{O}, \mathrm{CuSO}_{4} \cdot 5 \mathrm{H}_{2} \mathrm{O}$ or $\mathrm{CuCl}_{2} \cdot 2 \mathrm{H}_{2} \mathrm{O}$,), and SDAs (tetraethylenepentamine (TEPA), Triethylenetetramine (TETA) or Diethylenetriamine (DETA)) were adopted to fabricate $\mathrm{Cu} / \mathrm{SAPO}-34$ catalysts at hydrothermal temperature of $100-200{ }^{\circ} \mathrm{C}$ for $1-7$ days.

\subsection{Characterization}

The crystal structures of catalysts were analyzed by X-ray diffraction (XRD) via a computer controlled diffractometer (Rigaku D/max-2400) with $\mathrm{Cu} \operatorname{K} \alpha$ radiation $(\lambda=1.54178 \AA$ ) at the tube voltage of $40 \mathrm{kV}$ and the current of $100 \mathrm{~mA}$. The pore structure properties of catalysts were investigated by $\mathrm{N}_{2}$ adsorption-desorption measurements (Quantachrome autosorb-iQ $\mathrm{Q}_{2}$ Analyzer). The catalysts were degassed at $180{ }^{\circ} \mathrm{C}$ for $10 \mathrm{~h}$ under vacuum before measurements. The morphology of catalysts were examined by scanning electron microscope (SEM) (Philips XL-30FEG EDX). The elemental composition of catalysts was carried out by X-ray photoelectron spectroscopy (XPS) (Thermo SCIENTIFIC ESCALAB 250 spectrometer). The SCR activity of catalysts

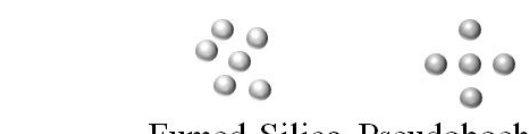

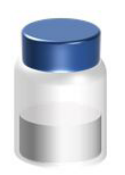

Phosphoric Acid

\section{Fumed Silica Pseudoboehmite}
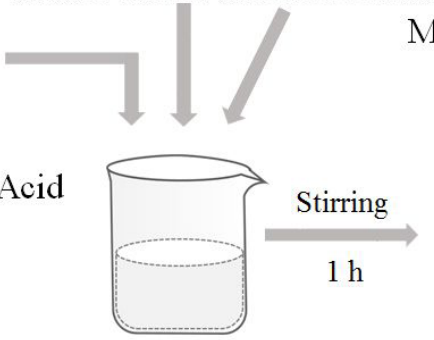

Deionized water
Metals ion sources

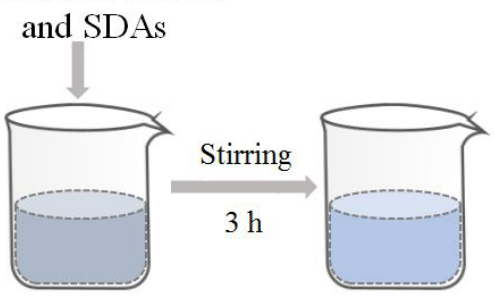

Homogeneous gel

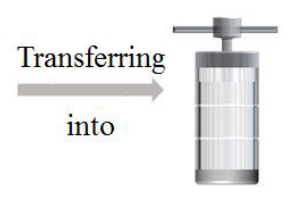

Teflon-lined autoclave

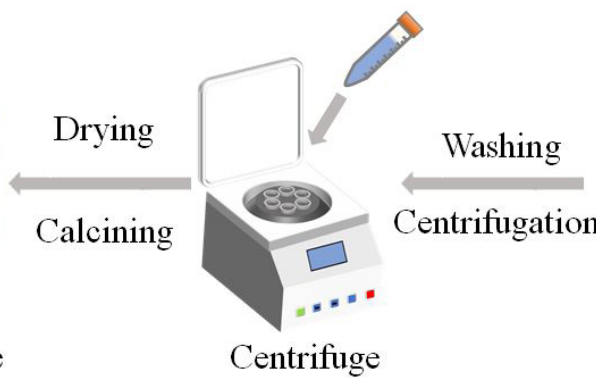

Centrifuge

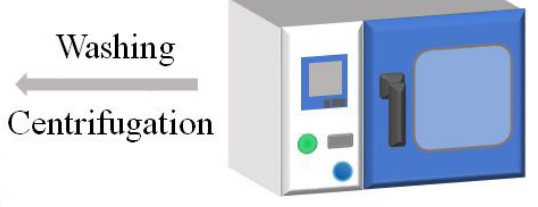

Drying oven
Muffle furnace 


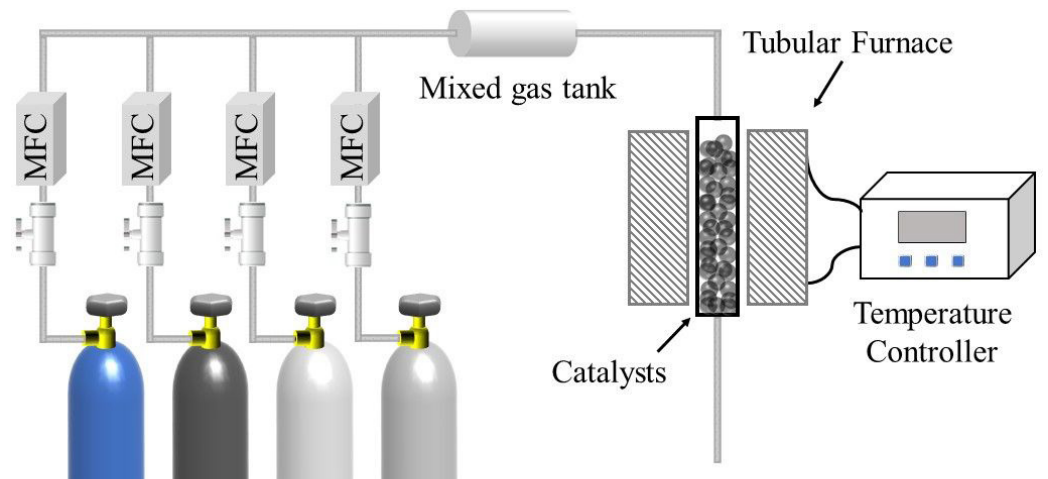

Gas analysis

Figure 2. Schematic diagram for catalytic activity measurement.

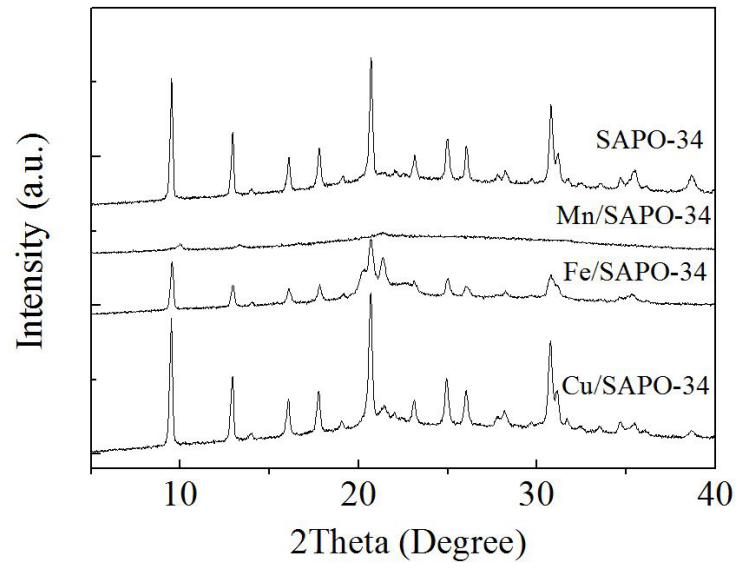

Figure 3. XRD patterns of SAPO-34 catalyst and SAPO-34 catalysts doped with different metal ion sources.

were measured in a fixed-bed quartz reactor. The schematic diagram of catalytic activity measurement was shown in Figure 2, and the detailed test process could refer to our previous paper ${ }^{31}$.

\section{Results and Discussion}

\subsection{Effects of incorporated metal ions}

For studying the effects of different metal ion sources on the resultant catalytic activity, the SAPO-34 catalysts doped with $\mathrm{Cu}^{2+}, \mathrm{Fe}^{3+}$ and $\mathrm{Mn}^{2+}$ were synthesized at $150{ }^{\circ} \mathrm{C}$ for 7 days. Figure 3 demonstrated the XRD patterns of SAPO-34, Cu/SAPO-34, Fe/SAPO-34 and Mn/SAPO-34 catalysts obtained under the same crystallization conditions. $\mathrm{Cu} / \mathrm{SAPO}-34$ catalyst possessed characteristic peaks of SAPO-34 at $2 \theta$ values $9.5^{\circ}, 12.7^{\circ}, 16^{\circ}, 21^{\circ}, 25^{\circ}$, and $32^{\circ}$ assigned to the chabazite phase, which agreed well with those SAPO-34 (JCPDS: 01-087-1527) in previous paper $^{32}$. The $\mathrm{Cu}$ precursor did not induce a significant effect on the crystal structure of the obtained sample. Fe/
SAPO-34 catalyst demonstrated similar characteristics with $\mathrm{Cu} / \mathrm{SAPO}-34$ catalyst, but indicated slightly weak peak intensities ${ }^{33,34}$. Subsequently, the degree of crystallinity was calculated by dividing the area of crystalline peaks by the total area under the diffraction curve (crystalline plus amorphous peaks). The degrees of crystallinity for these catalysts were $85.4 \%$ for SAPO-34, 80.94\% for Fe/SAPO-34, 88.32\% for Cu/SAPO-34 respectively, which further supported the above discussion. However, as for Mn/SAPO-34 catalyst, the XRD pattern indicated a predominance of amorphous material. The calculated crystallinity of Mn/SAPO-34 was only $32.58 \%$, which was much lower than that of SAPO-34 (85.4\%), implying the destruction of the catalyst structure after the introduction of $\mathrm{Mn}^{2+}$ in SAPO-34.

The SEM images shown in Figure 4 presented the morphology of these catalysts. All of the three metalincorporated SAPO-34 samples were cubic-like catalysts. $\mathrm{Cu} / \mathrm{SAPO}-34$ catalyst showed relatively intact microstructure with cubic-like morphology, which were similar with SAPO34. However, for Fe/SAPO-34 and Mn/SAPO-34 catalysts, they all demonstrated larger size than SAPO-34. We also observed some broken crystal fragments appeared on the surface of Fe/SAPO-34 catalyst and even more broken cubic-like structure existed in Mn/SAPO-34 catalyst, which were responsible for the decrease of crystallinity, agreeing with the XRD analysis. Figure 5 provided the nitric oxide conversion rate of the three catalysts. It displayed that when using $\mathrm{Cu}$ and $\mathrm{Fe}$ species as active centers, the resultant catalyst indicated high catalytic activity for nitric oxide conversion than SAPO-34 and Mn/SAPO-34 catalyst. The active temperature window of $\mathrm{Cu} / \mathrm{SAPO}-34$ catalyst was wider $\left(150-550{ }^{\circ} \mathrm{C}\right)$, while the Fe/SAPO-34 catalyst was slightly narrower $\left(200-450{ }^{\circ} \mathrm{C}\right)$, and the conversion rate of the $\mathrm{Cu} / \mathrm{SAPO}-34$ catalyst remained above $80 \%$ during $450-600{ }^{\circ} \mathrm{C}$. Based on the above analysis, it was concluded that loading copper ions could greatly improve the crystallinity and active temperature windows compared with other metal ions. Therefore, copper ions were selected as the catalytic active center of SAPO-34. 


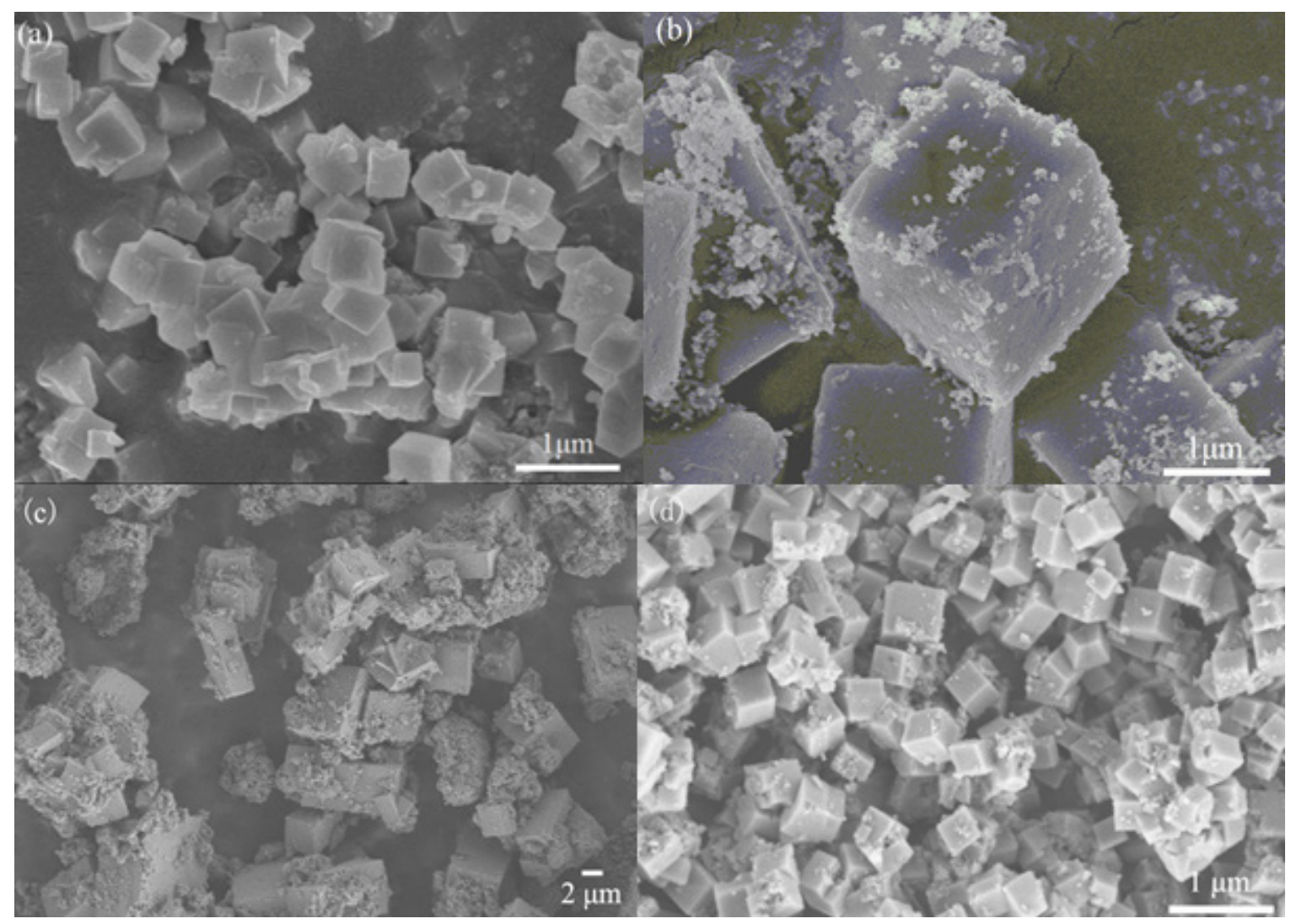

Figure 4. SEM images of various SAPO-34 catalysts: (a) Cu/SAPO-34; (b) Fe/SAPO-34; (c) Mn/SAPO-34; (d) SAPO-34.

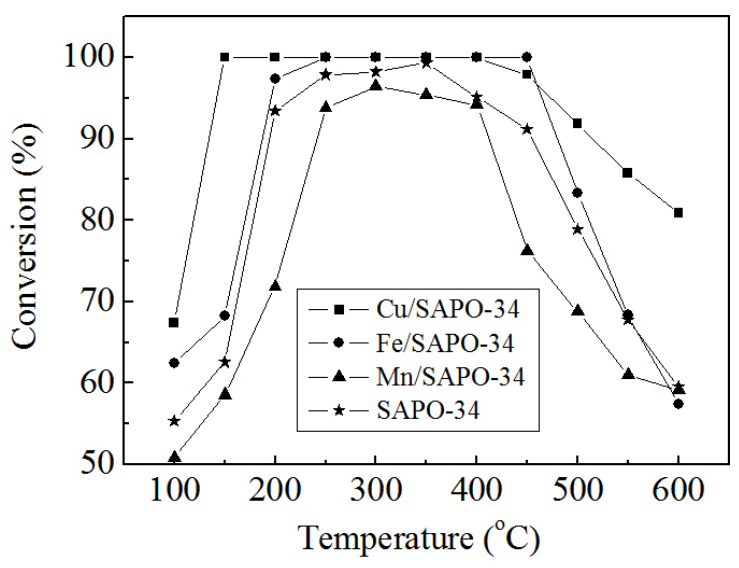

Figure 5. Nitric oxide conversion rate for the SAPO-34 at different metal ion sources.

\subsection{Effects of copper ion sources}

After defined copper ions were the favorable active site of SAPO-34 catalyst, we further investigated the relationship between different $\mathrm{Cu}^{2+}$ sources $\left(\mathrm{Cu}(\mathrm{COOH})_{2}, \mathrm{CuSO}_{4}, \mathrm{CuCl}_{2}\right.$, $\mathrm{Cu}\left(\mathrm{NO}_{3}\right)_{2}$, and) and SCR performance. It was obvious that the characteristic peaks were observed in all of the four catalysts synthesized at $150^{\circ} \mathrm{C}$ for 7 days (Figure 6), which agreed with those reported in the literatures ${ }^{30,35}$, and indicated $\mathrm{Cu} / \mathrm{SAPO}-34$ catalysts with the four types of $\mathrm{Cu}^{2+}$ sources were all successfully obtained. There were no significant different on diffraction peaks derived from different copper ion sources, which implied that the crystalline structure of the catalysts were almost not affected by the copper ion sources. The degrees of crystallinity for these four catalysts were also very close, which were $88.32 \%, 87.94 \%, 86.87 \%$, $87.49 \%$ for $\mathrm{Cu}(\mathrm{COOH})_{2}, \mathrm{CuSO}_{4}, \mathrm{CuCl}_{2}, \mathrm{Cu}\left(\mathrm{NO}_{3}\right)_{2}$ as $\mathrm{Cu}^{2+}$ sources, respectively. SEM images further confirmed the result from XRD analysis. Although different copper ion sources were adopted, the morphologies of these resultant catalysts were similar, and they all showed cubic-like microstructures (Figure 7).

The XPS wide scan spectrum of the $\mathrm{Cu} / \mathrm{SAPO}-34$ catalyst was presented in Figure 8a. Al, $\mathrm{Si}, \mathrm{Cu}, \mathrm{P}, \mathrm{C}, \mathrm{N}$ and $\mathrm{O}$ were detected in, displaying the obtained catalyst was SAPO-34 structure containing $\mathrm{Cu}^{2+}$. Figure $8 \mathrm{~b}$ presented the high resolution spectrum of $\mathrm{Cu} 2 \mathrm{p}$, which displayed two shake-up satellite peaks at 935.6 and $955.3 \mathrm{eV}$, corresponding to $\mathrm{Cu}$ $2 \mathrm{p}_{3 / 2}$ and $\mathrm{Cu} 2 \mathrm{p}_{1 / 2}$, respectively. Generally, these two peaks were used as a characteristic to determine copper ions, implying that copper ions had been successfully loaded in SAPO-34 catalyst and mainly existed as the $\mathrm{Cu}^{2+}$ state $^{36,37}$.

The result of nitrogen adsorption-desorption isotherms of $\mathrm{Cu} / \mathrm{SAPO}-34$ was showed in Figure 9. All catalysts demonstrated typical IV curves with the hysteresis loop. The BET surface area ranged from $232.49-250.29 \mathrm{~m}^{2} / \mathrm{g}$, especially, the largest BET surface area was derived from $\mathrm{Cu}\left(\mathrm{CH}_{3} \mathrm{COO}\right)_{2}$, with $250.29 \mathrm{~m}^{2} / \mathrm{g}$ and performed strong adsorption and desorption capacity. 
Figure 10 provided that nitric oxide conversion rates of $\mathrm{Cu} / \mathrm{SAPO}-34$ catalysts obtained from four kinds of $\mathrm{Cu}^{2+}$ sources. It can observed that the effects of $\mathrm{Cu}^{2+}$ sources on the nitric oxide conversion rates of the resultant $\mathrm{Cu} / \mathrm{SAPO}-$ 34 catalysts were not significant. Combined with the above analysis on their morphologies and nitrogen adsorptiondesorption characteristics, $\mathrm{Cu}\left(\mathrm{CH}_{3} \mathrm{COO}\right)_{2}$ was recommended as the candidate $\mathrm{Cu}^{2+}$ source for the subsequent experiments.

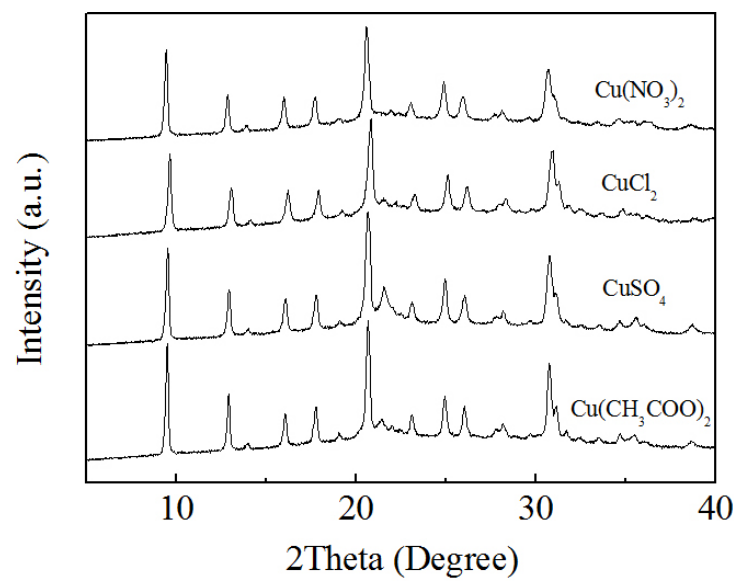

Figure 6. XRD patterns of $\mathrm{Cu} / \mathrm{SAPO}-34$ catalysts with different copper ion sources.

\subsection{Effects of SDAs}

As we known, during the crystallization process, the SDAs play important roles on the physicochemical properties of the synthesized catalysts because of their structure-directing, charge-compensating and space-filling roles ${ }^{34}$. For investigating the effects of SDAs on the performance of catalysts, three SDAs (TEPA, TETA, and DETA) were investigated. XRD patterns of $\mathrm{Cu} / \mathrm{SAPO}-34$ catalysts synthesized by the three SDAs at $150{ }^{\circ} \mathrm{C}$ for 7 days were showed in Figure 11. Obviously, the $\mathrm{Cu} / \mathrm{SAPO}-34$ catalyst synthesized by DETA did not demonstrate the typical characteristic peaks of SAPO34 , which meant that DETA was easy to produce structure defects in the formation of $\mathrm{Cu} / \mathrm{SAPO}-34$. However, the $\mathrm{Cu} / \mathrm{SAPO}-34$ catalysts adopted TEPA and TETA as SDAs exhibited the chabazite phase of SAPO-34, and the former had a stronger peak intensities, which might be attributed to its good crystal structure. The degrees of crystallinity for the three catalysts were calculated as $88.32 \%, 83.65 \%$, and $77.16 \%$ for TEPA, TETA, and DETA as SDAs, respectively, which agreed with the above analysis.

Figure 12 showed the SEM images of $\mathrm{Cu} / \mathrm{SAPO}-34$ catalysts synthesized by the three SDAs. Obviously, the integrity of cubic-like structure of these catalysts was in the order: TEPA $>$ TETA $>$ DETA, and the Cu/SAPO-34 catalyst obtained by using TEPA maintained higher crystal integrity, thus might possess more microspores and active

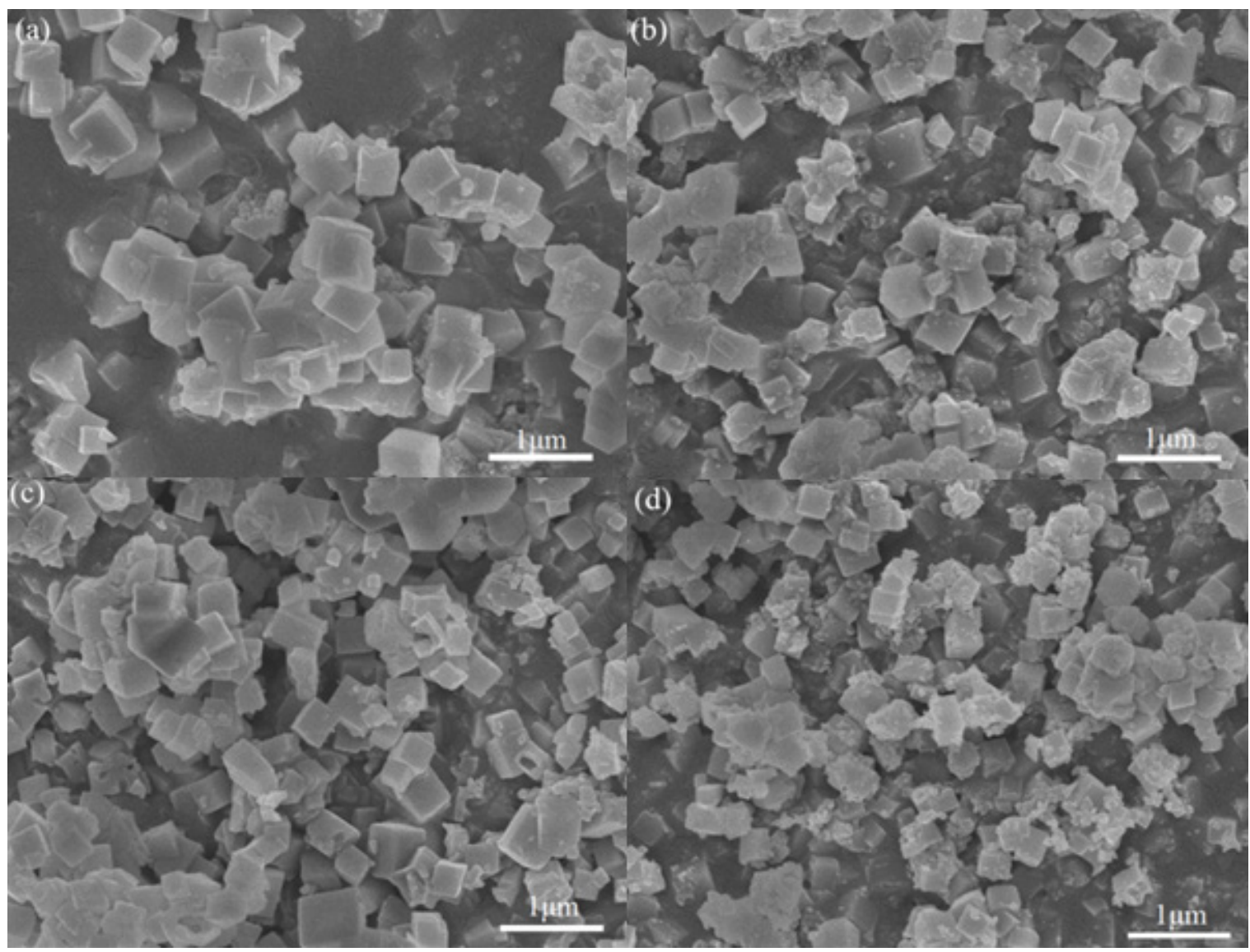

Figure 7. SEM image of $\mathrm{Cu} / \mathrm{SAPO}-34$ with different copper ion sources: (a) $\mathrm{Cu}\left(\mathrm{CH}_{3} \mathrm{COO}\right)_{2}$; (b) $\mathrm{CuSO}_{4} ;$ (c) $\mathrm{CuCl}_{2}$; (d) $\mathrm{Cu}\left(\mathrm{NO}_{3}\right)_{2}$. 


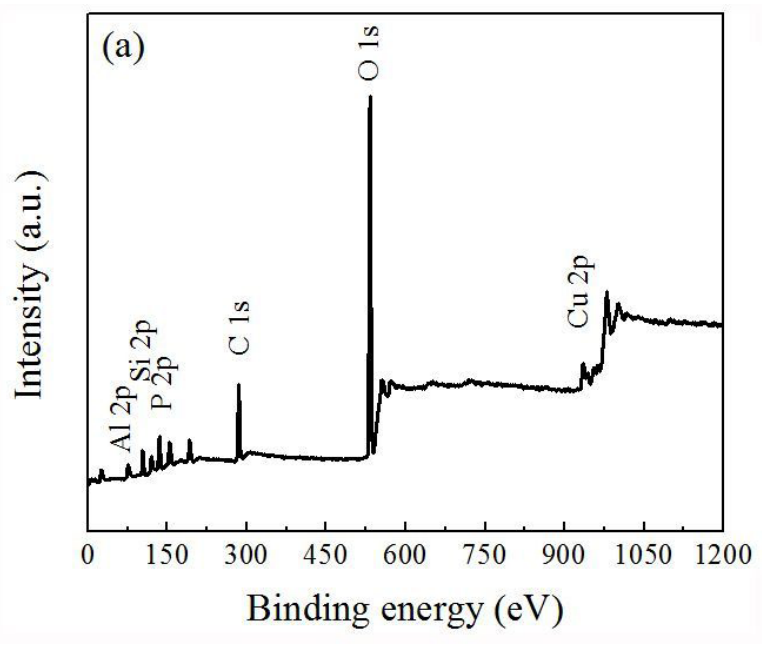

Figure 8. XPS spectra of Cu/SAPO-34: (a) survey, (b) $\mathrm{Cu} 2 \mathrm{p}$.

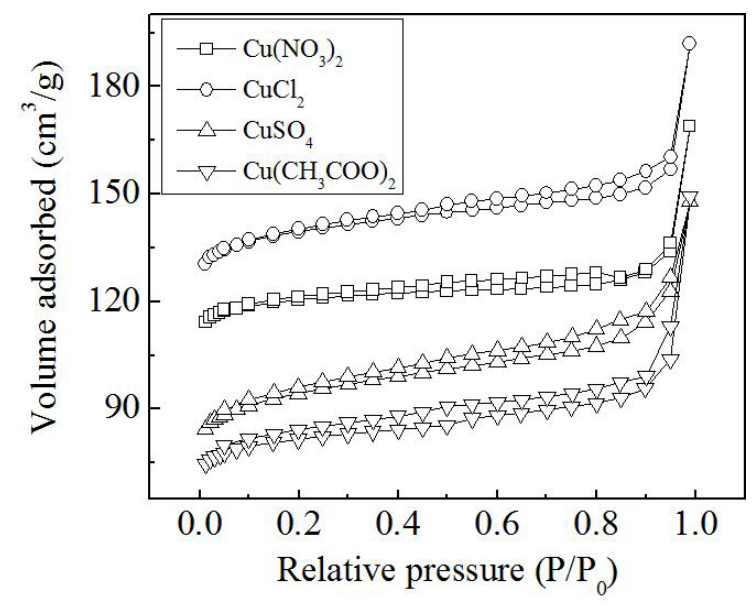

Figure 9. Nitrogen adsorption-desorption curves of $\mathrm{Cu} / \mathrm{SAPO}-34$ catalysts.

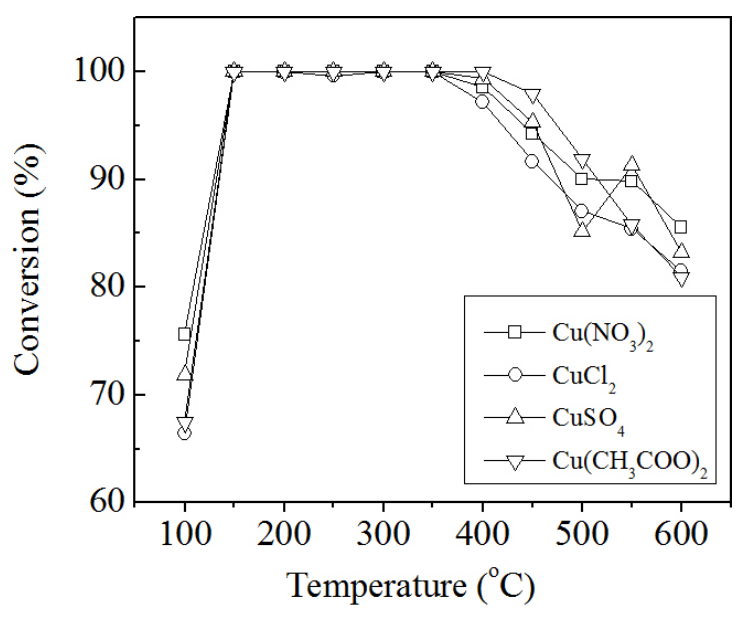

Figure 10. Nitric oxide conversion rate for the $\mathrm{Cu} / \mathrm{SAPO}-34$ at different copper ions species.

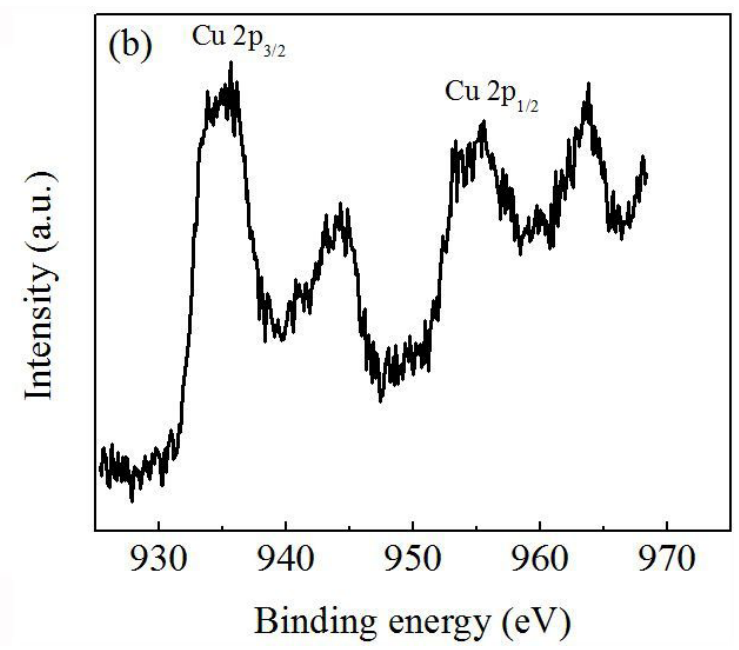

sites, which produced higher SCR catalytic activity ${ }^{38}$. However, as for the $\mathrm{Cu} / \mathrm{SAPO}-34$ catalyst prepared from DETA, the incomplete cubic-like structure was observed, which might suppress the diffusion of reactants, declining its catalytic activity.

$\mathrm{N}_{2}$ adsorption-desorption isotherms were presented in Figure 13. They all demonstrated typical type IV curves, and the corresponding BET surface area of DETA, TETA and TEPA were $40.18 \mathrm{~m}^{2} / \mathrm{g}, 224.89 \mathrm{~m}^{2} / \mathrm{g}$ and $250.29 \mathrm{~m}^{2} / \mathrm{g}$, respectively. The result indicated TEPA had the largest surface areas with strong adsorption and desorption ability for SCR reaction.

Figure 14 presented the nitric oxide conversion rates of the three $\mathrm{Cu} / \mathrm{SAPO}-34$ catalysts. When using DETA as SDA, the catalytic activity was extremely unstable throughout the temperature range, and the conversion rate of nitric oxide was significantly low than other two catalysts due to its broken crystal structure. The nitric oxide conversion rates of the $\mathrm{Cu} / \mathrm{SAPO}-34$ catalysts obtained by TEPA and TETA as SDAs were rather close with active temperature window range from $150-450{ }^{\circ} \mathrm{C}$. The difference between them was reflected in their catalytic activity above $450{ }^{\circ} \mathrm{C}$, and the reduction of catalytic activity of the former was less than that of the latter.

Sum up, the microstructure and morphology of SAPO-34 varied with the use of different SDAs because SDAs could affect $\mathrm{Si}$ coordination structure in SAPO- $34^{39}$, which further influenced $\mathrm{Cu}$ species distribution in the resultant $\mathrm{Cu} /$ SAPO-34 catalyst. Accordingly, the $\mathrm{Cu} / \mathrm{SAPO}-34$ catalyst derived from TEPA possessed the largest surface area, demonstrating highest NOx conversion, which agreed with previous results on large specific surface area favored high catalytic activity ${ }^{40}$. Therefore, it was the optimal choice to adopt TEPA as SDA.

\subsection{Effects of hydrothermal temperature}

For studying the influence of hydrothermal temperature on the structure, morphology, and nitric oxide conversion rate of $\mathrm{Cu} / \mathrm{SAPO}-34$ catalysts synthesized at 7 days, XRD 
analysis was firstly carried out. The crystallinity of $\mathrm{Cu}$ / SAPO-34 was improved as the hydrothermal temperature increased from 100 to $180{ }^{\circ} \mathrm{C}$, and slightly declined at $200{ }^{\circ} \mathrm{C}$ (Figure 15). The degrees of crystallinity for these catalysts demonstrated similar trend, which were $30.14 \%$, $39.47 \%, 88.32 \%, 88.54 \%$, and $87.62 \%$ for the hydrothermal

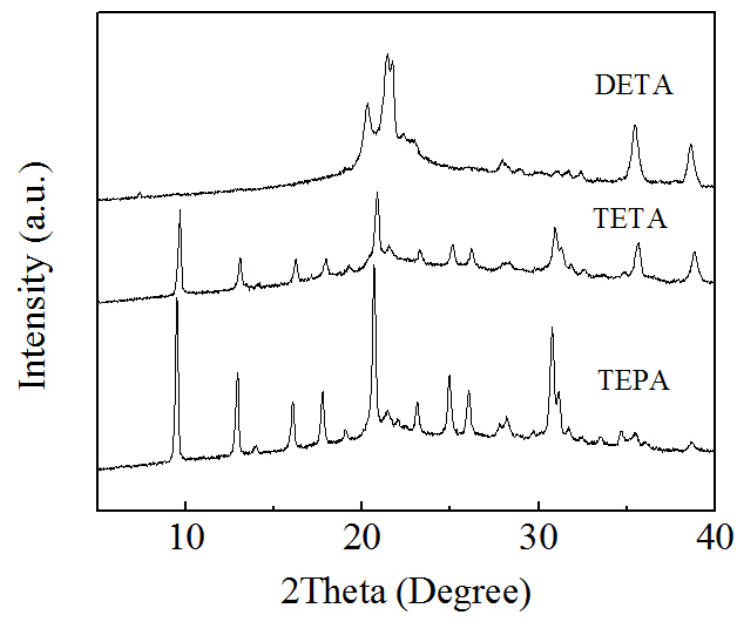

Figure 11. XRD patterns of $\mathrm{Cu} / \mathrm{SAPO}-34$ catalysts with different SDAs. temperature of $100{ }^{\circ} \mathrm{C}, 120^{\circ} \mathrm{C}, 150{ }^{\circ} \mathrm{C}, 180{ }^{\circ} \mathrm{C}$, and $200{ }^{\circ} \mathrm{C}$, respectively. Especially, for the $\mathrm{Cu} / \mathrm{SAPO}-34$ samples obtained at 100 and $120^{\circ} \mathrm{C}$, all diffraction peaks did not appear and an amorphous phase was found, which indicated the low hydrothermal temperature could not meet the requirement to synthesize $\mathrm{Cu} / \mathrm{SAPO}-34$.

As shown in Figure 16, at low hydrothermal temperature, the synthetic material was irregular fragment crystals, which were basically amorphous substances. The result meant that when the hydrothermal temperature was too low, it was hard to form cubic-like $\mathrm{Cu} / \mathrm{SAPO}-34$ catalyst. When increasing the hydrothermal temperature to above $150{ }^{\circ} \mathrm{C}$, the cubic-like $\mathrm{Cu} / \mathrm{SAPO}-34$ catalyst started to be formed. The surface of the catalyst was smoother and there was almost no debris crystal attached. Further improved to $200{ }^{\circ} \mathrm{C}$, the crystal size of the catalyst became slight bigger than those catalysts synthesized at other hydrothermal temperatures, which might be attributed to that the crystallization rate of the catalysts were fast at high hydrothermal temperature ${ }^{41}$.

Figure 17 showed nitric oxide conversion rate of $\mathrm{Cu} / \mathrm{SAPO}$ 34 catalysts obtained at various hydrothermal temperatures. Obviously, when the temperature reached $150^{\circ} \mathrm{C}$, the active temperature window was $150-550{ }^{\circ} \mathrm{C}$, and the removal rate of nitric oxide almost reached $100 \%$ at $150-450{ }^{\circ} \mathrm{C}$. Therefore, the hydrothermal temperature of $150{ }^{\circ} \mathrm{C}$ was recommended for nitric oxide removal in this work.

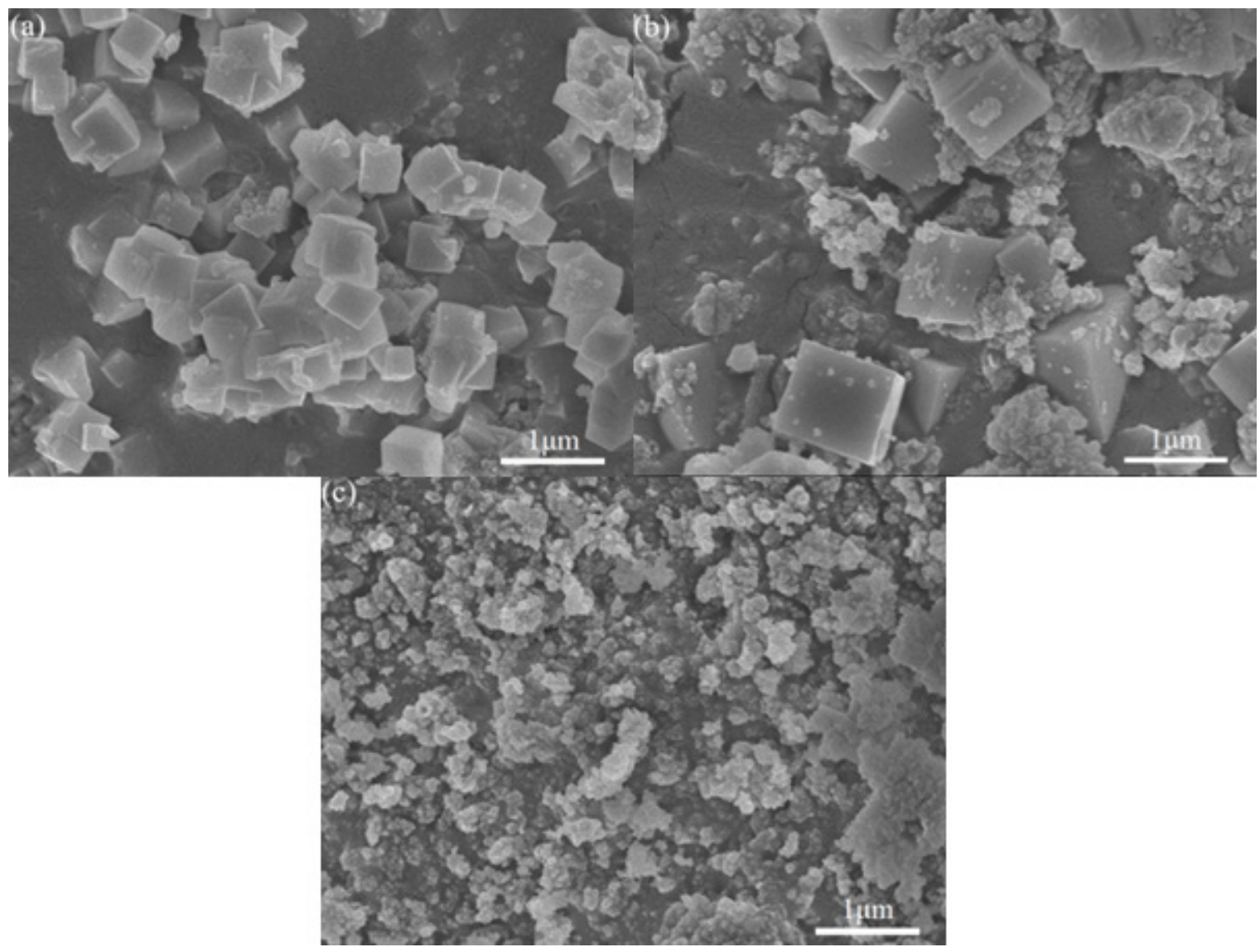

Figure 12. SEM images of Cu/SAPO-34 with different SDAs: (a) TEPA; (b) TETA; (c) DETA. 


\section{5 Effects of hydrothermal time}

The influences of hydrothermal time on the structure, morphology, and removal efficiency of nitric oxide of $\mathrm{Cu} / \mathrm{SAPO}-34$ catalyst synthesized at $150{ }^{\circ} \mathrm{C}$ were further

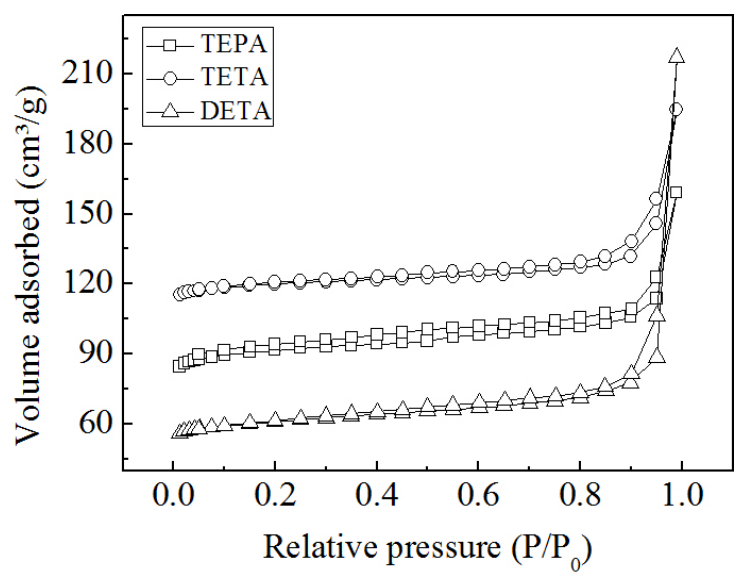

Figure 13. $\mathrm{N}_{2}$ adsorption-desorption isotherms of $\mathrm{Cu} / \mathrm{SAPO}-34$ catalysts.

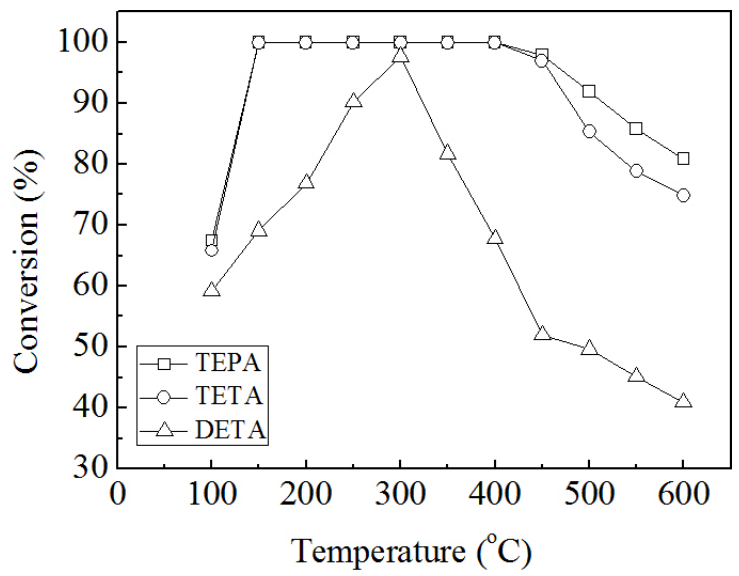

Figure 14. Nitric oxide conversion rates for the $\mathrm{Cu} / \mathrm{SAPO}-34$ at different SDAs.

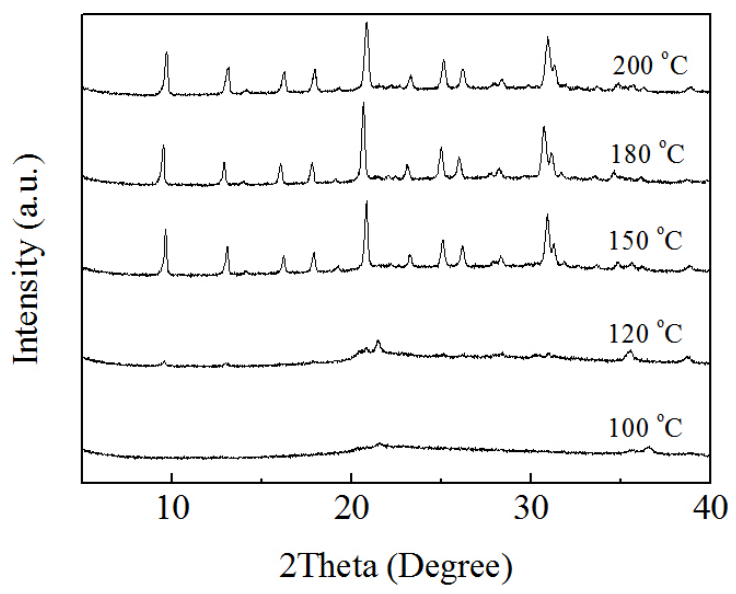

Figure 15. XRD patterns of $\mathrm{Cu} / \mathrm{SAPO}-34$ catalysts with various hydrothermal temperatures. evaluated. Obviously, short hydrothermal time (1 day) led to the produce of $\mathrm{Cu} / \mathrm{SAPO}-34$ catalyst with poor crystallinity (Figure 18), which was calculated as $79.06 \%$. Improving the hydrothermal time to 3 days, the stronger peak intensities were indicated, suggesting the formation $\mathrm{Cu} / \mathrm{SAPO}-34$ catalyst with good crystallinity $(85.77 \%)$. Extending the hydrothermal time to 7 days, the peak intensities were further increased, the degrees of crystallinity was improved to $88.32 \%$. The SEM images provided by Figure 19 also approved the conclusion from XRD analysis. At 1 day of hydrothermal time, incomplete cubic-like structure was observed. When the hydrothermal reaction exceeded 3 days, the synthesized $\mathrm{Cu} / \mathrm{SAPO}-34$ catalysts revealed relatively complete cubic-like morphology.

Figure 20 presented the nitric oxide conversion rates of $\mathrm{Cu} / \mathrm{SAPO}-34$ catalysts synthesized at the hydrothermal time of 1, 3, and 7 days, respectively. Obviously, the nitric oxide conversion rates of the three $\mathrm{Cu} / \mathrm{SAPO}-34$ catalysts were improved dramatically with the increase of reaction temperature below $150{ }^{\circ} \mathrm{C}$, and then stayed stable. As the reaction temperature exceeded $350{ }^{\circ} \mathrm{C}$, the nitric oxide conversion rate began to decline for the $\mathrm{Cu} / \mathrm{SAPO}-34$ catalyst synthesized at short hydrothermal time (1 day). However, for the two $\mathrm{Cu} / \mathrm{SAPO}-34$ catalysts synthesized at 3 and 7 days, almost the same trends on nitric oxide conversion rates were observed before $500{ }^{\circ} \mathrm{C}$, however, slight high nitric oxide conversion rates were observed due to its good crystallinity at long hydrothermal time.

Four kinds of reported $\mathrm{Cu} / \mathrm{SAPO}-34$ catalysts (ionexchange method and one-pot method) were used for comparison with our catalysts. Wang et al. ${ }^{26}$ reported the ion-exchanged $\mathrm{Cu} / \mathrm{SAPO}-34$ catalyst, which demonstrated low catalyst activity (about $20 \%-70 \%$ of nitric oxide conversion rate) below $350{ }^{\circ} \mathrm{C}$, and even at the high reaction temperature range of $350-550{ }^{\circ} \mathrm{C}$, the nitric oxide conversion rates only remained at about $70-80 \%$. Liu et al. ${ }^{27}$ presented their work on ion-exchanged $\mathrm{Cu} /$ SAPO-34 catalyst, and the catalyst indicated high catalyst activity (above $80 \%$ of nitric oxide conversion rate) at reaction temperature range of 200-350 ${ }^{\circ} \mathrm{C}$. As for "one-pot" synthesized Cu/SAPAO-34 catalysts, they usually demonstrated higher catalyst activity than those obtained by ion-exchange method. For example, Martínez-Franco et al. ${ }^{29}$ fabricated high activity $\mathrm{Cu}$ / SAPAO-34 catalyst via one-pot method. The resultant catalyst showed excellent catalyst activity (above $80 \%$ of nitric oxide conversion rate) at the whole reaction temperature range $\left(200-500{ }^{\circ} \mathrm{C}\right)$, and especially at 250 $400{ }^{\circ} \mathrm{C}$, nitric oxide conversion rate reached $100 \%$. Tang et al. ${ }^{30}$ got high activity $\mathrm{Cu} / \mathrm{SAPAO}-34$ catalyst via one-pot method, and nitric oxide conversion rates were above $80 \%$ at reaction temperature of $200-600{ }^{\circ} \mathrm{C}$. In this work, we also obtained the $\mathrm{Cu} / \mathrm{SAPAO}-34$ catalyst by one-pot hydrothermal method, its catalyst activity was close to that obtained by Martínez-Franco et al. ${ }^{29}$ by one-pot method, and higher than those fabricated by Tang et al. ${ }^{30}$ via one-pot method, and Wang et al. ${ }^{26}$ and Liu et al. ${ }^{27}$ via ion-exchange method. 


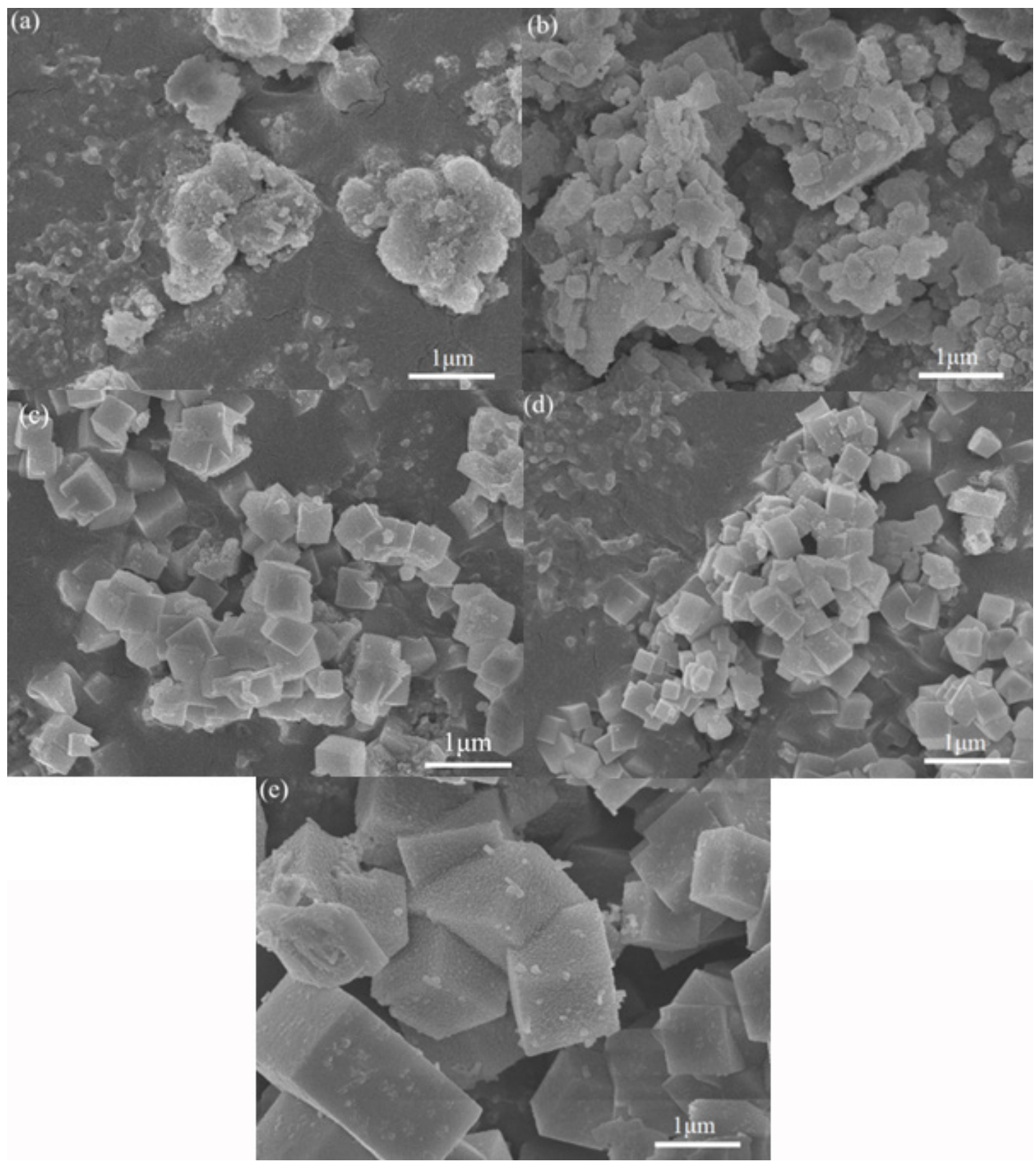

Figure 16. SEM images of Cu/SAPO-34 catalyst:(a) $100{ }^{\circ} \mathrm{C}$;(b) $120^{\circ} \mathrm{C}$;(c) $150{ }^{\circ} \mathrm{C}$;(d) $180{ }^{\circ} \mathrm{C}$;(e) $200{ }^{\circ} \mathrm{C}$.

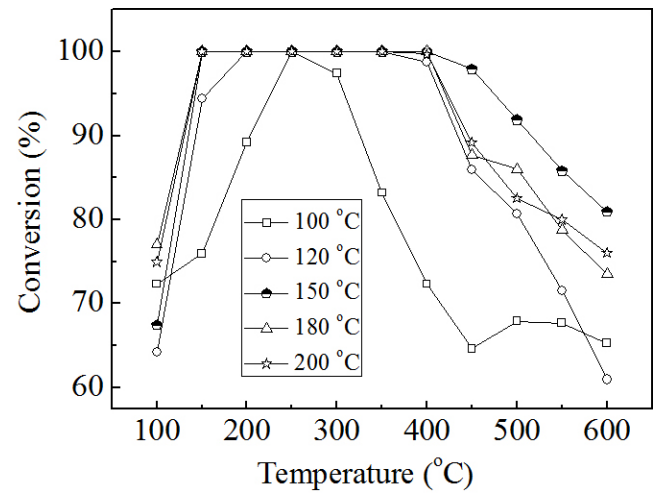

Figure 17. Nitric oxide conversion rate for the $\mathrm{Cu} / \mathrm{SAPO}-34$ at different hydrothermal temperatures.

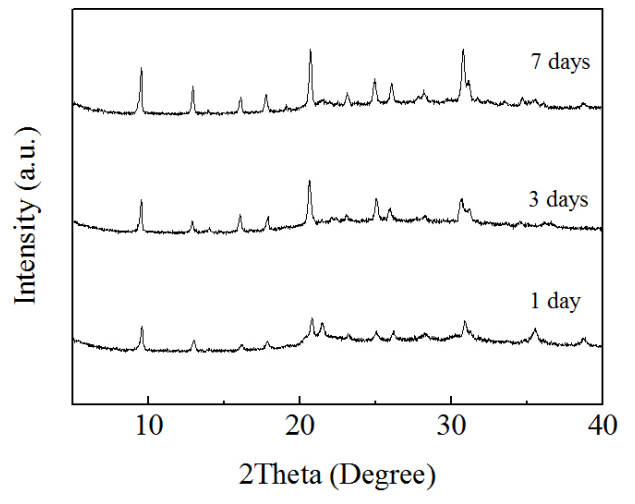

Figure 18. XRD patterns of $\mathrm{Cu} / \mathrm{SAPO}-34$ catalysts at different hydrothermal time. 


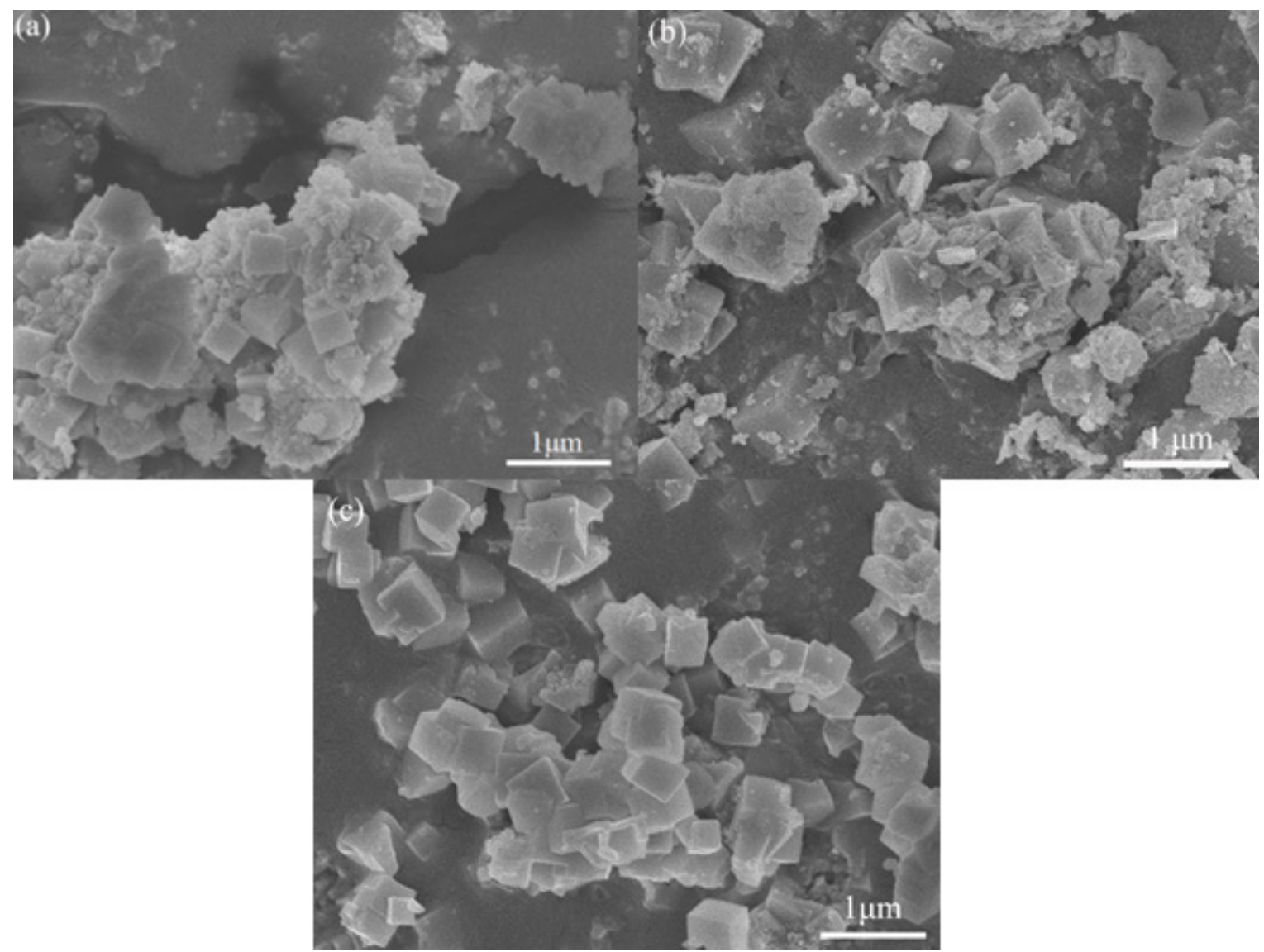

Figure 19. SEM images of $\mathrm{Cu} / \mathrm{SAPO}-34$ catalyst at different hydrothermal time: (a) 1 day; (b) 3 days; (c) 7 days.

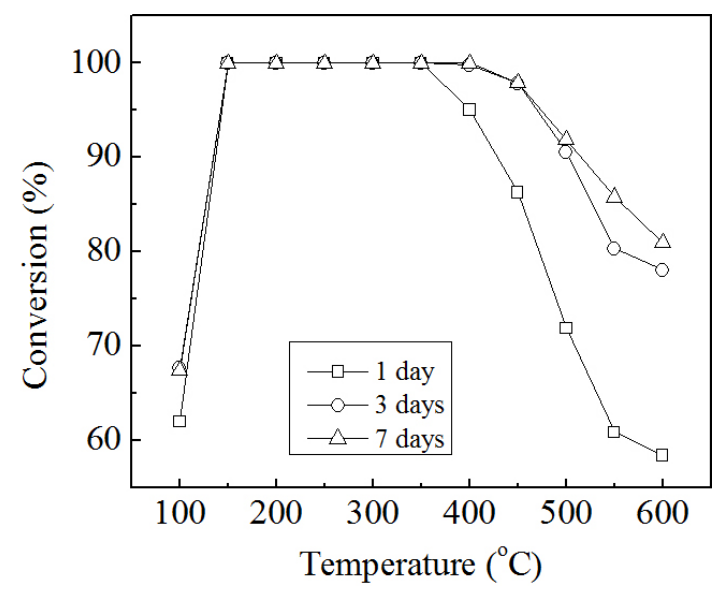

Figure 20. Nitric oxide conversion rates for the $\mathrm{Cu} / \mathrm{SAPO}-34$ at different hydrothermal time.

\section{Conclusion}

In summary, we have successfully fabricated various metal-incorporated SAPO-34 catalysts via one-step hydrothermal synthesis. Among them, $\mathrm{Cu} / \mathrm{SAPO}-34$ catalysts demonstrated complete microstructure with cubic morphology, wide temperature window, and high nitric oxide conversion rate. Subsequently, A series of $\mathrm{Cu} / \mathrm{SAPO}-34$ catalysts were synthesized using four kinds of copper salts $\left(\mathrm{CuSO}_{4}, \mathrm{Cu}\left(\mathrm{NO}_{3}\right)_{2}\right.$, $\mathrm{CuCl}_{2}$, and $\mathrm{Cu}(\mathrm{COOH})_{2}$ ) as $\mathrm{Cu}^{2+}$ sources, and found that $\mathrm{Cu}^{2+}$ sources did not produce significant influence on the nitric oxide conversion rates of the resultant $\mathrm{Cu} / \mathrm{SAPO}-34$ catalyst. SDAs had an important impact on properties of the synthesized $\mathrm{Cu} / \mathrm{SAPO}-34$ catalysts, and the $\mathrm{Cu} / \mathrm{SAPO}-34$ catalyst adopting TEPA as SDA could maintain higher crystal integrity and active sites, which were benefit to the SCR reaction. Furthermore, hydrothermal temperature and time had significant influences on the formation of $\mathrm{Cu} / \mathrm{SAPO}-34$ catalyst. When the hydrothermal temperature was higher than $150^{\circ} \mathrm{C}$ and the hydrothermal time was longer than 3 days, the $\mathrm{Cu} / \mathrm{SAPO}-34$ catalyst with a cubic-like structure and high catalyst activity could be obtained.

\section{Acknowledgement}

This work was supported by the National Natural Science Foundation of China (21476034) and Key Research $\&$ Development Project of Liaoning Province (2017308005).

\section{References}

1. Huang X, Zhang S, Chen H, Zhong Q. Selective catalytic reduction of $\mathrm{NO}$ with $\mathrm{NH}_{3}$ over $\mathrm{V}_{2} \mathrm{O}_{5}$ supported on $\mathrm{TiO}_{2}$ and $\mathrm{Al}_{2} \mathrm{O}_{3}$ : a comparative study. J Mol Struct. 2015;1098:289-97.

2. Skalska K, Miller JS, Ledakowicz S. Trends in NOx abatement: a review. Sci Total Environ. 2010;408:3976-89. 
3. Kompio PGWA, Brückner A, Hipler F, Auer G, Löffler E, Grünert W. A new view on the relations between tungsten and vanadium in $\mathrm{V}_{2} \mathrm{O}_{5}-\mathrm{WO}_{3} / \mathrm{TiO}_{2}$ catalysts for the selective reduction of $\mathrm{NO}$ with $\mathrm{NH}_{3}$. J Catal. 2012;286:237-47.

4. Yang J, Sun R, Sun S, Zhao N, Hao N, Chen H, et al. Experimental study on NOx reduction from staging combustion of high volatile pulverized coals. Part 1. Air staging. Fuel Process Technol. 2014;126:266-75.

5. Ma Z, Wu X, Si Z, Weng D, Ma J, Xu T. Impacts of niobia loading on active sites and surface acidity in $\mathrm{NbOx} / \mathrm{CeO}_{2}-\mathrm{ZrO}_{2}$ $\mathrm{NH}_{3}-\mathrm{SCR}$ catalysts. Appl Catal B. 2015;179:380-94.

6. Koebel M, Elsener M, Kleemann M. Urea-SCR: a promising technique to reduce NOx emissions from automotive diesel engines. Catal Today. 2000;59:335-45.

7. Ma Z, Yang $\mathrm{H}$, Liu F, Zhang X. Interaction between $\mathrm{SO}_{2}$ and $\mathrm{Fe}-\mathrm{Cu}-\mathrm{Ox} / \mathrm{CNTs}-\mathrm{TiO}_{2}$ catalyst and its influence on $\mathrm{NO}$ reduction with $\mathrm{NH}_{3}$. Applied Catalysis A. 2013;467:450-5.

8. Song Z, Zhang Q, Ning P, Fan J, Duan Y, Liu X, et al. Effect of $\mathrm{CeO}_{2}$ support on the selective catalytic reduction of $\mathrm{NO}$ with $\mathrm{NH}_{3}$ over P-W/CeO ${ }_{2}$. J Taiwan Inst Chem Engrs. 2016;65:149-61.

9. Mees FDP, Martens LRM, Janssen MJG, Verberckmoes AA. Vansant EFImprovement of the hydrothermal stability of SAPO-34. Chem Commun. 2003;1:44-5.

10. Briend M, Vomscheid R, Peltre MJ, Man PP, Barthomeuf D. Influence of the choice of the template on the short- and long-term stability of SAPO-34 zeolite. J Chem Phys. 1995;99:8270-6.

11. Wang D, Tian P, Yang M, Xu S, Fan D, Su X, et al. Synthesis of SAPO-34 with alkanolamines as novel templates and their application for $\mathrm{CO}_{2}$ separation. Microporous Mesoporous Mater. 2014;194:8-14.

12. Gao F, Wang Y, Kollár M, Washton NM, Szanyi J, Peden CHF. A comparative kinetics study between $\mathrm{Cu} / \mathrm{SSZ}-13$ and Fe/SSZ13 SCR catalysts. Catal Today. 2015;258:347-58.

13. Martínez-Franco R, Moliner M, Thogersen JR, Corma A. Efficient one-pot preparation of Cu-SSZ-13 materials using cooperative OSDAs for their catalytic application in the SCR of NOx. ChemCatChem. 2013;5:3316-23.

14. Gao F, Kollár M, Kukkadapu RK, Washton NM, Wang Y, Szanyi J, et al. Fe/SSZ-13 as an $\mathrm{NH}_{3}$-SCR catalyst: a reaction kinetics and FTIR/Mössbauer spectroscopic study. Appl Catal B. $2015 ; 164: 407-19$.

15. Wen C, Geng L, Han L, Wang J, Chang L, Feng G, et al. A comparative first principles study on trivalent ion incorporated SSZ-13 zeolites. Phys Chem Chem Phys. 2015;17:29586-96.

16. Carja G, Kameshima Y, Okada K, Madhusoodana CD. Mn-Ce/ ZSM5 as a new superior catalyst for $\mathrm{NO}$ reduction with $\mathrm{NH}_{3}$. Appl Catal B. 2007;73:60-4.

17. Liu Z, Yi Y, Zhang S, Zhu T, Zhu J, Wang J. Selective catalytic reduction of $\mathrm{NOx}$ with $\mathrm{NH}_{3}$ over Mn-Ce mixed oxide catalyst at low temperatures. Catal Today. 2013;216:76-81.

18. Cao F, Su S, Xiang J, Wang P, Hu S, Sun L, et al. The activity and mechanism study of $\mathrm{Fe}-\mathrm{Mn}-\mathrm{Ce} / \gamma-\mathrm{Al}_{2} \mathrm{O}_{3}$ catalyst for low temperature selective catalytic reduction of $\mathrm{NO}$ with $\mathrm{NH}_{3}$. Fuel. 2015;139:232-9.

19. Wang J, Fan D, Yu T, Wang J, Teng H, Hu X, et al. Improvement of low-temperature hydrothermal stability of $\mathrm{Cu} / \mathrm{SAPO}-34$ catalysts by $\mathrm{Cu}^{2+}$ species. J Catal. 2015;322:84-90.

20. Fickel DW, D'Addio E, Lauterbach JA, Lobo RF. The ammonia selective catalytic reduction activity of copper-exchanged small-pore zeolites. Appl Catal B. 2011;102:441-8.

21. Ma L, Cheng Y, Cavataio G, McCabe RW, Fu L, Li J. Characterization of commercial Cu-SSZ-13 and $\mathrm{Cu}-\mathrm{SAPO}-34$ catalysts with hydrothermal treatment for $\mathrm{NH}_{3}-\mathrm{SCR}$ of $\mathrm{NOx}$ in diesel exhaust. Chem Eng J. 2013;225:323-30.

22. Fan S, Xue J, Yu T, Fan D, Hao T, Shen M, et al. The effect of synthesis methods on $\mathrm{Cu}$ species and active sites over $\mathrm{Cu} / \mathrm{SAPO}-$ 34 for $\mathrm{NH}_{3}$-SCR reaction. Catal Sci Technol. 2013;3:2357-64.

23. Liu Z, Tang L, Chang L, Wang J, Bao W. In situ synthesis of $\mathrm{Cu}-\mathrm{SAPO}-34$ /cordierite for the catalytic removal of NOx from diesel vehicles by $\mathrm{C}_{3} \mathrm{H}_{8}$. Chin J Catal. 2011;32:546-54.
24. Martínez-Franco R, Moliner M, Concepcion P, Thogersen JR, Corma A. Synthesis, characterization and reactivity of high hydrothermally stable $\mathrm{Cu}-\mathrm{SAPO}-34$ materials prepared by “one-pot" processes. J Catal. 2014;314:73-82.

25. Wang J, Yu T, Wang X, Qi G, Xue J, Shen M, et al. The influence of silicon on the catalytic properties of $\mathrm{Cu} / \mathrm{SAPO}-34$ for NOx reduction by ammonia-SCR. Appl Catal B. 2012;127:137-47.

26. Wang L, Li W, Qi G, Weng D. Location and nature of Cu species in $\mathrm{Cu} / \mathrm{SAPO}-34$ for selective catalytic reduction of $\mathrm{NO}$ with $\mathrm{NH}_{3}$. J Catal. 2012;289:21-9.

27. Liu X, Wu X, Weng D, Si Z, Ran R. Evolution of copper species on $\mathrm{Cu} / \mathrm{SAPO}-34 \mathrm{SCR}$ catalysts upon hydrothermal aging. Catal Today. 2017;281:596-604.

28. Cortés-Reyes M, Finocchio E, Herrera C, Larrubia MA, Alemany LJ, Busca G. A study of Cu-SAPO-34 catalysts for SCR of NOx by ammonia. Microporous Mesoporous Mater. 2016;241:258-65.

29. Martínez-Franco R, Moliner M, Franch C, Kustov A, Corma A. Rational direct synthesis methodology of very active and hydrothermally stable Cu-SAPO-34 molecular sieves for the SCR of NOx. Appl Catal B. 2012;127:273-80.

30. Tang J, Xu M, Yu T, Ma H, Shen M, Wang J. Catalytic deactivation mechanism research over $\mathrm{Cu} / \mathrm{SAPO}-34$ catalysts for $\mathrm{NH}_{3}-\mathrm{SCR}$ (II): the impact of copper loading. Chem Eng Sci. 2017; 168:414-22.

31. Tao P, Sun MH, Qu SC, Song CW, Li C, Yin YY, et al. Effects of $\mathrm{V}_{2} \mathrm{O}_{5}$ and $\mathrm{WO}_{3}$ loadings on the catalytic performance of $\mathrm{V}_{2} \mathrm{O}_{5}-\mathrm{WO}_{3} / \mathrm{TiO}_{2}$ catalyst for $\mathrm{SCR}$ of $\mathrm{NO}$ with $\mathrm{NH}_{3}$. Glob NEST J. 2017;19(1):160-6.

32. Mirza K, Ghadiri M, Haghighi M, Afghan A. Hydrothermal synthesize of modified Fe, Ag and K-SAPO-34 nanostructured catalysts used in methanol conversion to light olefins. Microporous Mesoporous Mater. 2018;260:155-65.

33. Wei Y, Zhang D, Xu L, Chang F, He Y, Meng S, et al. Synthesis, characterization and catalytic performance of metal-incorporated SAPO-34 for chloromethane transformation to light olefins. Catal Today. 2008;131:262-9.

34. Sena FC, de Souza BF, de Almeida NC, Cardoso JS, Fernandes LD. Influence of framework composition over SAPO-34 and MeAPSO-34 acidity. Applied Catalysis A. 2011;406:59-62.

35. Wang J, Peng Z, Chen Y, Bao W, Chang L, Feng G. In-situ hydrothermal synthesis of $\mathrm{Cu}-\mathrm{SSZ}-13$ /cordierite for the catalytic removal of NOx from diesel vehicles by $\mathrm{NH}_{3}$. Chem Eng J. 2015;263:9-19.

36. Wang J, Chen Y, Tang L, Bao W, Chang L, Han L. One-step hydrothermal synthesis of $\mathrm{Cu}-\mathrm{SAPO}-34$ /cordierite and its catalytic performance on NOx removal from diesel vehicles. Trans Nonferrous Met Soc China. 2013;23:3330-6.

37. Liu J, Yu F, Liu J, Cui L, Zhao Z, Wei Y, et al. Synthesis and kinetics investigation of meso-microporous $\mathrm{Cu}-\mathrm{SAPO}-34$ catalysts for the selective catalytic reduction of $\mathrm{NO}$ with ammonia. J Environ Sci. 2016;48:45-58.

38. Feng X, Lin Q, Cao Y, Zhang H, Li Y, Xu H, et al. Neodymium promotion on the low-temperature hydrothermal stability of a $\mathrm{Cu} / \mathrm{SAPO}-34 \mathrm{NH}_{3}-\mathrm{SCR}$ monolith catalyst. J Taiwan Inst Chem Engrs. 2017;80:805-12.

39. Pastore HO, Coluccia S, Marchese L. Porous Aluminophosphates: from molecular sieves to designed acid catalysts. Annu Rev Mater Res. 2005;35:351-95.

40. Li J, Song Z, Ning P, Zhang Q, Liu X, Li H, et al. Influence of calcination temperature on selective catalytic reduction of $\mathrm{NOx}$ with $\mathrm{NH}_{3}$ over $\mathrm{CeO}_{2}-\mathrm{ZrO}_{2}-\mathrm{WO}_{3}$ catalyst. J Rare Earths. 2015;33:726-35.

41. Wang X, Li R, Bakhtiar SH, Yuan F, Li Z, Zhu Y. Excellent catalytic performance for methanol to olefins over SAPO-34 synthesized by controlling hydrothermal temperature. Catal Commun. 2018;108:64-7. 